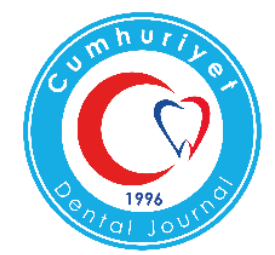

\title{
AWARENESS ABOUT PERIODONTITIS AND PRE-TERM LOW BIRTH WEIGHT INFANTS AMONG GYNECOLOGISTS IN CHENNAI- A QUESTIONNAIRE STUDY
}

\author{
Chennaideki Jinekologların Periodontitis ve Düşük Doğum Ağırlıklı Prematüre Bebekler \\ Hakkındaki Farkındalı̆̆ı: Bir Anket Çalı̧̧ması
}

Hafsa ISMAIL, Radhika ARJUNKUMAR

\begin{abstract}
Makale Kodu/Article Code : 201578
Makale Gönderilme Tarihi $\quad$ : 25.06 .2016

Kabul Tarihi

: 28.03.2017
\end{abstract}

\section{ABSTRACT}

Background: Periodontal infection has been associated with adverse pregnancy outcomes. Subsequently it is important that gynecologists are educated about hormonal effects on women's oral health. The current study assessed gynecologist's awareness regarding the effect of female sex hormones on periodontal health and preterm delivery.

Materials and methods: Sixty-six gynecologists from the city of Chennai completed a questionnaire regarding awareness about female hormonal and periodontal health and its effects on preterm low birth weight infants. Respondents were divided into three groups: Group A, (doctors who practiced at a medical colleges) Group B (doctors who practiced at private hospitals) and Group C. (doctors who practiced at both medical colleges and private hospitals) Survey responses were collected and data between the groups were statistically compared.

Results: Our findings showed that most gynecologists were aware and concerned about female patient's oral health during various hormonal phases. However, gynecologists practicing at medical colleges (Group A) and gynecologists practicing at both medical colleges and private hospitals (Group C) had significantly greater health awareness than doctors practicing at private hospitals. (Group B)

Conclusion: The results of the current study imply the fact that there is adequate knowledge about the effects of hormonal changes in the periodontal tissues. However, there is limited incorporation of this knowledge, especially among gynecologists who are exclusively into private practice.

Keywords: Periodontitis, preterm low birth weight, scaling, root planing
ÖZ

Amaç: Periodontal enfeksiyon, gebeliğin olumsuz sonuçlarıyla ilişkilendirilmiştir. Bundan dolayı jinekologların kadınların ağız sağlığı üzerindeki hormonal etkileri konusunda eğitim alması önemlidir. Mevcut araştırma kadın seks hormonlarının periodontal sağlık ve erken doğum üzerindeki etkileri konusundaki jinekoloğun farkındalığını değerlendirdi.

Gereç ve yöntem: Chennai şehrinden altmış altı jinekolog, kadınlarda hormonal ve periodontal sağlık ile düşük doğum ağırlıklı prematüre bebeklere etkileri konusundaki bir anketi doldurdu. Katılımcılar, A Grubu (tıp fakültesinde çalışan jinekologlar), B Grubu (özel hastanelerde çalışan jinekologlar) ve C Grubu (hem tıp fakültelerinde hem de özel hastanelerde çalışan jinekologlar) olmak üzere üç gruba ayrıldı. Anket yanıtları toplandı ve gruplar arasındaki veriler istatistiksel olarak karşılaştırıldı.

Bulgular: Çalışmanın sonuçları, çoğu jinekoloğun, çeşitli hormonal fazlarda kadın hastalarının ağız sağlığı konusunda bilgili olduklarını ve endişe duyduğunu ortaya koymuştur. Bununla birlikte, tıp fakültelerinde çalışan jinekologlar (Grup A) ve hem tıp fakültelerinde hem de özel hastanelerde çalışan jinekologlar (Grup C), özel hastanelerde çalışan doktorlardan (Grup B) istatiksel olarak anlamlı derecede daha fazla sağlık bilincine sahip bulundu.

Sonuç: $\mathrm{Bu}$ çalışmanın sonuçları, hormonal değişikliklerin periodontal dokular üzerindeki etkileri hakkında yeterli bilgi bulunduğu sunmaktadır. Bununla birlikte, bu bilginin, özellikle özel hastanelerde çalışan jinekologlar arasında sınırlı bir şekilde göz önünde bulundurulması söz konusudur.

Anahtar Sözcükler: Periodontitis, prematüre düşük doğum ağırlığı, diş yüzeyi temizliği, kök yüzeyi düzleştirme 


\section{INTRODUCTION}

A high prevalence of periodontitis is noted among adults regardless of sex, race, education, residence or socio economic status. Changes in female sex hormone levels during pregnancy are related to the enhanced susceptibility to gingival inflammation. ${ }^{1}$ Female sex hormones have a multifunctional influence on the periodontal condition in different parts of the life cycle in women. ${ }^{2}$ These hormones also play an important role in the pathogenesis of pregnancy related gingivitis. ${ }^{3}$ Increased sex steroid hormone levels can cause edema in tissues by increasing the vascular permeability and cellular proliferation in blood vessels. ${ }^{4,5}$ Elevated estradiol and progesterone concentrations during pregnancy alter the quality of subgingival microbiota towards a higher anaerobeaerobe ratio by favoring the growth of certain gram-negative anaerobes in the oral cavity. ${ }^{6}$

Research clearly demonstrates that puberty, menstrual cycle, pregnancy, oral contraception use and menopause affect gingival tissue. Since gynecologists assess and treat women across their life span and during these hormonal changes, it is important that these doctors understand the influence of hormonal fluctuations on a women's periodontal health. Pre-term low birth weight infants (those infants who are born in less than 37 weeks of gestation and have a birth weight of less than 2500 grams) are prone to various abnormalities like respiratory problems, neurodevelopmental problems and congenital problems. ${ }^{7}$ There are various causes of such preterm low birth weight deliveries and periodontal infection is said to be one of them. ${ }^{8}$ Gestational length can be affected by both generalised infections, including viral respiratory infections, diarrhoea and malaria and more localised infections of the genital and urinary systems. ${ }^{9-12}$

A periodontal infection may influence the pregnancy outcomes by providing a source of gram-negative anaerobic organisms and bacterial components such as lipopolysaccharides. These can trigger release of immune mediators such as PGE2 and TNF$\alpha$, which is normally involved in normal parturition, and in turn, may influence the course of pregnancy. ${ }^{13,14}$ Therefore, this study assesses gynecologists' knowledge regarding the awareness about female hormonal and periodontal health and its effects on pre-term low birth weight infants.

\section{MATERIALS AND METHODS}

A cross sectional survey was conducted among 100 gynecologists in Chennai among which 66 responded to the survey. Survey responders were divided into three groups based upon institutional practice. Group A included doctors practicing at a medical college, Group $\mathrm{B}$ included doctors practicing at private hospitals and Group C included doctors practicing at both medical college and private hospitals. The questionnaire (Table 1) was individually distributed and answers were collected.

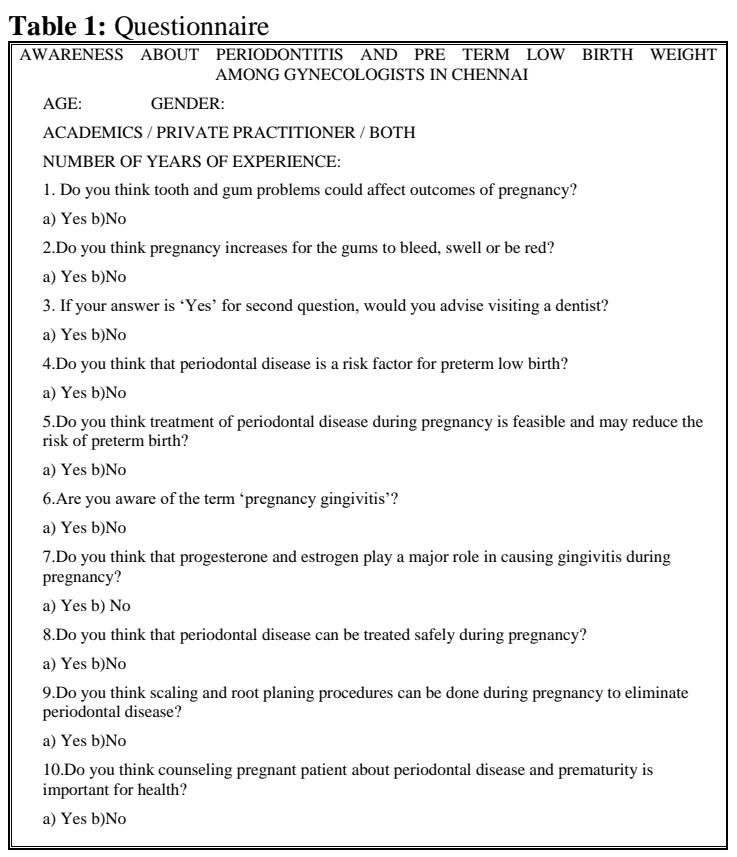

Respondents' data were statistically analyzed. The Chi square test was used to determine statistically significant difference between 
groups A, B and C. The collected data was analysed with SPSS 16.0 version.To describe about the data descriptive statistics, frequency analysis,percentage analysis, mean and S.D were used. To find the significance between the variables Pearson's Chi-Square test was used.In the above statistical tool the probability value .05 is considered as significant level.

\section{RESULTS}

About sixty six gynecologists completed the questionnaire. There were sixty-five females and one male gynecologist who participated in the survey. Of the sixty six doctors, 27 doctors belonged to Group A, 20 doctors belonged to Group B and 19 doctors belonged to Group C. The results showed that Group A and group C doctors believed it was more important to refer patients for dental care compared to Group B doctors. In fact, table 2, shows a significant difeference in the responses as about $92.5 \%$ of Group A gynecologists and $78.9 \%$ of Group C doctors would refer cases of gingival tissue changes to a periodontist for further dental health, compared to only $60 \%$ of Group B gynaecologists. $(\mathrm{p}=0.026)$

Table 2: Survey Responses

\begin{tabular}{|c|c|c|c|c|}
\hline & & $\begin{array}{c}\text { Academics } \\
(\%)\end{array}$ & $\begin{array}{c}\text { Private } \\
\text { practitioner(\%) }\end{array}$ & $\begin{array}{l}\text { Both } \\
(\%)\end{array}$ \\
\hline \multirow{2}{*}{$\begin{array}{l}\text { 1.Do you think tooth and } \\
\text { gum problems could } \\
\text { affect outcomes of } \\
\text { pregnancy? }\end{array}$} & Yes & $27(100 \%)$ & $20(100 \%)$ & $19(100 \%)$ \\
\hline & No & 0 & 0 & 0 \\
\hline \multirow{2}{*}{$\begin{array}{l}\text { 2.Do you think pregnancy } \\
\text { increases gums to bleed, } \\
\text { swell or be red? }\end{array}$} & Yes & $27(100 \%)$ & $20(100 \%)$ & $19(100 \%)$ \\
\hline & No & 0 & 0 & 0 \\
\hline \multirow{2}{*}{$\begin{array}{l}\text { 3.If your answer is 'Yes" } \\
\text { for second question, } \\
\text { would you advise visiting } \\
\text { a dentist? }\end{array}$} & Yes & $25(92.5 \%)$ & $12(60 \%)$ & $15(78.9 \%)$ \\
\hline & No & $2(7.4 \%)$ & $8(40 \%)$ & $4(421 \%)$ \\
\hline \multirow{2}{*}{$\begin{array}{l}\text { 4.Do you think } \\
\text { periodontal disease is a } \\
\text { risk factor for preterm low } \\
\text { birth? }\end{array}$} & Yes & $27(100 \%)$ & $20(100 \%)$ & $19(100 \%)$ \\
\hline & No & 0 & 0 & 0 \\
\hline \multirow{2}{*}{$\begin{array}{l}\text { 5.Do you think treatment } \\
\text { of periodontal disease } \\
\text { during pregnancy reduces } \\
\text { the risk of preterm birth? }\end{array}$} & Yes & $27(100 \%)$ & $20(100 \%)$ & $19(100 \%)$ \\
\hline & No & 0 & 0 & 0 \\
\hline \multirow{2}{*}{$\begin{array}{l}\text { 6.Are you aware of term } \\
\text { 'pregnancy gingivitis'? }\end{array}$} & Yes & $27(100 \%)$ & $20(100 \%)$ & $19(100 \%)$ \\
\hline & No & 0 & 0 & 0 \\
\hline \multirow{2}{*}{$\begin{array}{c}\text { 7.Do you think } \\
\text { progesterone \& estrogen } \\
\text { play a major role in } \\
\text { causing gingivitis during } \\
\text { pregnancy? }\end{array}$} & Yes & $27(100 \%)$ & $20(100 \%)$ & $19(100 \%)$ \\
\hline & No & 0 & 0 & 0 \\
\hline \multirow{2}{*}{$\begin{array}{c}\text { 8.Do you think } \\
\text { periodontal disease can be } \\
\text { treated during pregnancy? }\end{array}$} & Yes & $27(100 \%)$ & $18(100 \%)$ & $19(100 \%)$ \\
\hline & No & 0 & $2(10 \%)$ & 0) \\
\hline \multirow{2}{*}{$\begin{array}{l}\text { 9.Do you think scaling \& } \\
\text { root planning can be done } \\
\text { during pregnancy to } \\
\text { eliminate periodontal } \\
\text { disease? }\end{array}$} & Yes & $26(96.2 \%)$ & $14(70 \%)$ & $19(100 \%)$ \\
\hline & No & $1(3.7 \%)$ & $6(30 \%)$ & 0 \\
\hline \multirow{2}{*}{$\begin{array}{c}\text { 10.Do you think } \\
\text { counseling pregnant } \\
\text { patients about periodontal } \\
\text { disease \& prematurity is } \\
\text { important for health? }\end{array}$} & Yes & $27(100 \%)$ & $11(55 \%)$ & $19(100 \%)$ \\
\hline & No & 0 & $9(45 \%)$ & 0 \\
\hline
\end{tabular}

Groups A, B and C expressed similar beliefs on all other survey questions. For example, almost all the doctors are well aware about the relation between periodontal health and female hormones. Hundred percent of the doctors agreed that hormonal fluctuations may change gingival tissue across a woman's reproductive phase.There was no significant differences in response for question number 5 that is all gynecologists agreed that treatment of periodontal disease during pregnancy is feasible and may reduce the risk of preterm birth.

Almost all gynecologists agreed that periodontal disease is a risk factor for 'Preterm Low Birth Weight'. When asked if periodontal disease can be treated during pregnancy almost all gynecologists agreed in the affirmative with a statistically insignificant difference in the responses across the 3 groups. ( $\mathrm{p}=0.093$ ) The results also show that about $96.2 \%$ gynecologists from Group A, 70\% gynecologists from Group B and 100\% gynecologists from Group $\mathrm{C}$ agreed that scaling and root planing procedures can be done during pregnancy to eliminate periodontal disease with a statistically significant response between group A and B. $(p=0.003)$ when asked about whether counselling a pregnant patient about periodontal disease and prematurity is important for health shows that only $100 \%$ of the respondents in group $\mathrm{A}$ and $\mathrm{C}$ agreed to that whereas only $55 \%$ of the respondents in group B agreed to it implying the defeciency of knowledge or reluctance on the part of the gynecologists in private hospitals to inform and educate patients about the importance of periodontal infection and its relationship to adverse pregnancy outcomes. $(\mathrm{p}=0.00)$

\section{DISCUSSION}

Although several studies have investigated doctors' attitude and awareness of the association between oral health and pregnancy outcomes, the present study is unique because 
it assessed gynecologists' awareness of pregnancy outcomes in addition to knowledge about hormonal-induced gingival changes throughout a woman's reproductive phase. We found that most gynecologists were well educated and concerned about a female patient's oral health during different hormonal phases. Our findings contribute to the literature regarding gynecologists' knowledge of oral health, particularly periodontal health, for female patients. ${ }^{15,16}$

Our data showed that gynecologists from Group $\mathrm{A}$ and $\mathrm{C}$ demonstrated greater awareness of the need for dental follow-ups compared to gynecologists from Group B. The difference in awareness may be explained by the fact that doctors in medical colleges (Group A and Group C) are continually updated with current knowledge for teaching and research purposes. The present study showed that while all of the gynecologists knew about hormonal influences on the periodontium, a few private practitioners were less aware of the importance of a regular dental check up and the to counsel pregnant patients with regards to periodontal disease. These findings are supported by Wilder et al who concluded that obstetricians were well aware of periodontal disease as a potential risk factor for PLBW but showed limited incorporation of this knowledge into clinical practices. ${ }^{17}$ Almost all respondents agreed that hormonal fluctuations might induce gingival tissue changes across the female life cycle.

\section{CONCLUSION}

Preventive, routine and emergency dental care procedures should be provided to pregnant patients. Beyond treatment there is need for pregnancy specific preventive care and oral health education. It is recommended to arrange training both dentists and obstetricians in the oral health needs, screening and care of pregnant patients, as a part of parental care.

\section{REFERENCES}

1. Silness J, Loe H, Periodontal disease in pregnancy. II. Correlation between oral hygiene and periodontal condition. Acta Odontol Scand 1964; 22:121-135.

2. Gursoy M, Pajukanta R, Sorsa T, Kononen

E. Clinical changes in periodontium during pregnancy and post-partum. J Clin Periodontol 2008;35:576-83.

3. Lopez NJ, Smith PC, Gutierrez J. Periodontal therapy may reduce the risk of preterm low birth weight in women with periodontal disease: a randomized controlled trial. J Periodontol 2002 73:911-924.

4. Lindhe J, Branemark PI. Changes in vascular permeability after local application of sex hormones. J Periodontal Res 1967; 2:259265.

5. Lindhe J, Branemark PI, Lundskog J. Changes in vascular proliferation after local application of sex hormones. J Periodontal Res 1967; 2:266-272.

6. Kornman KS, Loesche WJ, The subgingival microbial flora during pregnancy. J Periodontal Res 1980;15:111-122.

7. BK Yeo, LP Lim, Periodontal disease the emergence of a risk for systemic conditions: Pre term Low birth weight. Ann Acad Med Singapore 2005; 34: 111-6.

8. Gibbs RS. The relationship between infection and adverse pregnancy outcomes: an overview. Ann Periodontol 2001;6:153-63

9. Bray RS, Anderson MJ. Falciparium malaria and pregnancy. Trans $\mathrm{R}$ isepeis Soc Trop Med Hyg 1979;73:427-31.

10. Andrews WW, Goldenberg RL, Hauth JC. Preterm labor: emerging role iscepof genital tract infections. Infect Agents Dis 1995;4:196-211.

11.Gibbs RS, Romeo R, Hillier SL, Eschenbach DA, Sweet RL. A review of premature birth and subclinical infection. Am J Obstet Gynecol is seppi1992;166:1515-26.

12. Minkoff H, Grunebaum AN, Schwarz RH, Feldman J, Cummings M, istepiCrombleholme $\mathrm{W}$, et al. Risk factors for premature rupture of membranes: a prospective study of the vagina 
flora in pregnancy. Am J Obstet Gynecol 1984;150:965-72.

13. Offenbacher S, Katz V, Fertik G, Collins J, Boyd D, Maynor G, et al. Periodontal infection as a possible risk factor for preterm low birth weight. J Periodontol 1996; 67:1103-13.

14.Scannapieco FA. Position paper of The American Academy of Periodontology: periodontal disease as a potential risk factor for systemic diseases. J Periodontol 1998;69:84150 .

15. Apoorva, S.M., Suchetha, A. Effect of sex hormones on periodontium. Indian J. Dent. Sci. 2010; 2: 36-40.

16. Nutalapati R, Ramisetti A, Mutthineni RB, Jampani ND, Kasagani SK. Awareness of association between periodontitis and PLBW among selected population of practising gynecologists in Andhra Pradesh. Indian J Dent Res 2011;22:735.

17.Wilder. R, Robinson.C, Jared.H.I. Obstetricians' knowledge and practice behaviors concerning periodontal health and preterm delivery and low birth weight. J Dent hyg.2007; 81(4)81.

\section{Correspondence Author}

Hafsa Ismail

Saveetha Dental College

Department of Periodontics

India.

E-mail: hafsa8@yahoo.in 